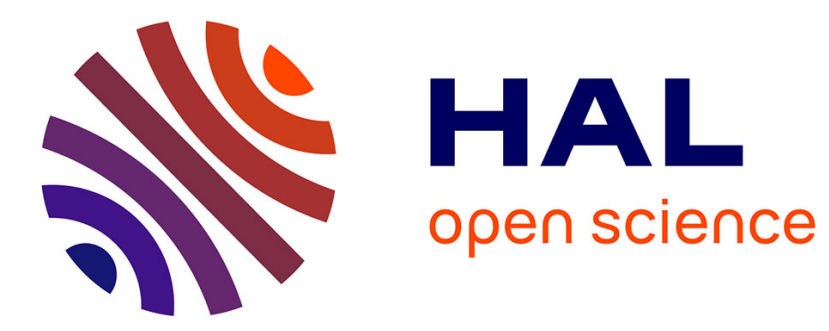

\title{
Philosophy as the Road to Good ICT
}

\author{
Iordanis Kavathatzopoulos, Ryoko Asai
}

\section{To cite this version:}

Iordanis Kavathatzopoulos, Ryoko Asai. Philosophy as the Road to Good ICT. 13th IFIP International Conference on Human Choice and Computers (HCC13), Sep 2018, Poznan, Poland. pp.293-298, 10.1007/978-3-319-99605-9_22 . hal-02001959

\section{HAL Id: hal-02001959 \\ https://hal.inria.fr/hal-02001959}

Submitted on 31 Jan 2019

HAL is a multi-disciplinary open access archive for the deposit and dissemination of scientific research documents, whether they are published or not. The documents may come from teaching and research institutions in France or abroad, or from public or private research centers.
L'archive ouverte pluridisciplinaire HAL, est destinée au dépôt et à la diffusion de documents scientifiques de niveau recherche, publiés ou non, émanant des établissements d'enseignement et de recherche français ou étrangers, des laboratoires publics ou privés. 


\title{
Philosophy as the road to good ICT
}

\author{
Iordanis Kavathatzopoulos ${ }^{1}$ (0000-0003-3806-5216), and Ryoko Asai ${ }^{2}(0000-0002-$ \\ 4035-3711) \\ ${ }^{1 \cdot 2}$ Uppsala University, Uppsala, Sweden \\ 1iordanis@it.uu.se \\ ${ }^{2}$ ryoko.asai@it.uu.se
}

\begin{abstract}
Handling satisfactorily ICT ethics issues in the design as well as in the use of systems, demands continuous adjustment to relevant values. In privacy, robotics and sustainability, this can be achieved through the development of personal thinking skills and the establishment and running of suitable group processes. In ethical decision making it is important to make a distinction between thinking as a process, and value-content as the result of this process. By focusing on the process, i.e. philosophizing, the philosophical method of deliberative thinking, we can construct and apply tools to support ethical decision making during the development and the use of ICT systems.
\end{abstract}

Keywords: Ethics $\bullet$ ICT $・$ Method $\bullet$ Moral $\bullet$ Philosophizing $\bullet$ Privacy $\bullet$ Robots, Sustainability $\bullet$ Tools.

\section{$1 \quad$ Introduction}

ICT affects our lives in an almost total way. Artificial intelligence and autonomous agents are both welcome and scaring. Our privacy is threatened while ICT gives us access to the information we need about other people. New technology may help us save the environment but at the same time it consumes huge amounts of energy and valuable minerals.

Although urgent, it is very difficult or impossible to find optimal solutions to the above issues. Conflicting interests and values decide what has to be done; not only between different groups but also inside the same person standing in front of a choice about ICT. Every thinkable answer contains both risks and possibilities. In our effort to find solutions we have always to negotiate and make compromises. Issues of robots, privacy and environment are difficult and contradicting, and they cannot be solved by making laws or rules based on wishful thinking about a perfect world. Conflicting conditions force us to choose different pathways to solutions than focusing on answers. Working with processes like regulating and shaping the process of finding definitions and answers seems to be the right approach. In that case, the focus is on tools, methods and skills to run a process of continuous creation and revision. 
A dialectic process is necessary in ICT issues in order to identify significant interests and values, and to formulate principles and policies. Handling robot, environment and privacy issues, and working for secure ICT systems demand continuous adjustment to relevant values as well as the necessary personal skills and suitable group processes. Focusing on the method and making sure that the right way of proceeding has been adopted is the way to get satisfactory answers to the problems of ICT security and privacy. The philosophical method of deliberative thinking, i.e. philosophizing, has to be the ground on which to build such methods and tools.

\section{Autonomous agents and robots}

The development of so called independent systems and robots that are capable of processing information and acting independently of their human operators, has been accelerated as well as the hopes, and the fears, of the impact of those artifacts on environment, market, society, and human life generally. Many ethical issues are raised because of these systems being today, or in the future, capable of independent decision making and acting. Will these IT systems or robots decide and act in the right way, or will they cause harm?

In situations where humans have difficulties perceiving and processing information, or making decisions and implementing actions, because of the quantity, variation and complexity of information, independent agents can be of great help to achieve goals and obtain optimal solutions to problems. One example of this is financial transactions where the speed and volume of information makes it impossible for human decision makers to take the right measures, for example in the case of an economic crisis. Another example is dangerous and risky situations, like natural disasters or battles in war, where the use of drones and military robots may help to avoid soldier injuries and deaths. A third example comes from human social and emotional needs, for example in elderly care where robots may play an important role providing necessary care as well as to be a companion to lonely elderly people.

It is clear that such ICT systems have to make decisions and act to achieve the goals for which they had been built in the first place. Will they make the right decisions and act in a proper way? Can we guarantee this by designing them in a suitable way? But if it is possible, do we really want such machines given the fact that their main advantage is their increasing independence and autonomy, and hence we do not want to constrain them too much?

There are many questions around this, most of which converge on the issue of moral or ethical decision making. The definition of what we mean by ethical or moral decision making or ethical/moral agency is a very much significant precondition for the design of proper ICT decision systems. Given that we have a clear definition we will be able to judge whether an ICT system is, 1) capable of making ethical decisions, and 2) able to make these decisions independently and autonomously. 


\section{Privacy}

Focus on the process of thinking and decision making is also valid regarding the issue of privacy. Privacy appears to be a very important issue today when ICT permeates more and more aspects of our life. Mainly this is understood as a risk of breaching the privacy of persons, and possibly the privacy of groups, organizations, corporations and states.

If we make an effort to describe the nature of privacy we can easily and rather fast come to the conclusion that privacy is not only something that has to be protected. Although this is important, underlined by both lines of definitions, it seems that privacy sometimes has to be diminished or intervened in order to satisfy important interests and values (see for example Tavani [10]). One is to create a bond to another person, group or organization. To achieve this one has to give access to private information, or even to give up a part or all limitations toward this special person or organization. It is a matter of trust between each other.

The other situation, which is the most common one, is that a person, group or organization, which we may call a separate entity, has always another important interest added to the interest of protecting its own privacy: To breach, diminish or intervene the privacy of any other entity that is a prospective or actual partner in any sense. It is very important for any entity to acquire access to the information about any other entity that is of some interest. The reason for that is the need for correct information. Every separate entity, with its privacy protected, releases only the information it wants the others to have. By that it wants to affect the other's decision making toward a preferred direction. On the other hand, the other entity's interest is to make the right decision and to achieve it access to correct information is a necessary condition. A right decision cannot be based solely on information controlled and supplied by the other entity.

If we now go back to the ways of approaching the issue of privacy, and look upon them through the glasses of our observations of its nature we may have good arguments to maintain that a process-focused approach is more helpful and fruitful. Given the controversial nature of privacy (protect it and breach it at the same time) and the clashes arising constantly between all entities in a social interaction, the focus cannot be on normative solutions which even if they work are always limited to a certain situation, but on the ways skills, methods and tools we use in order to create, revise and apply policies, guidelines, rules and principles to manage the issues of privacy.

\section{$4 \quad$ Environment and sustainability}

ICT has undoubtedly a heavy impact on environment. It may cause large environmental catastrophes or it may contribute positively to the protection of the environment. For example, building computer hardware demands a great amount of many different and special resources, running the systems consumes increasing amounts of energy, and disposing of computers pollutes the environment. 
Raw materials used in manufacturing computer hardware are very rare in nature and they can only be found on certain limited places on earth. Besides the risk of them drying up sooner rather than later, there is also a political risk. Production of necessary computer parts is conditional on the political will of foreign governments or on the actions of opposition groups or guerillas. If they hinder or stop mining and transportation of rare earths, production of computer hardware will suffer. Another sustainability risk, related to the above political risk, may also appear. It is about work environment conditions. Factories manufacturing computer hardware are established in countries where worker rights are not upheld properly and work environment is not protected enough. Producing computers in this way implies serious sustainability risks. Sooner or later there will be conflicts and protests will take place, or there will be radical restructures and relocations of production, leading to supply shortages of necessary hardware parts.

Once the hardware has been assembled to produce a whole computer machine and the software installed, the system will start to be used. But its use demands plenty of energy. And this energy has to be produced in some way, which in itself may be dangerous for the environment if it is of the sort called "dirty energy", i.e. use of fossil materials with a high content of carbon dioxide and pollutants. More, the need for energy to power the running of ICT systems is increasing, implying that more energy has to be produced in the future. It is not difficult to see that a big risk pertaining to the sustainability of ICT use emerges. But alongside the risk there is a possibility. The hope that ICT can be used as a tool to achieve reduced levels of energy consumption, for example, by allowing and supporting energy saving actions like teleconferencing or by using the power of ICT to calculate and coordinate better ways of organizing energy use or designing energy-saving technology. However, in the case of cloud computing and in spite of many optimistic plans and hopes, because of synergies of concentrating data storage and treatment, we see a clear increase in energy consumption.

Computers do not live forever. After some time they break down or become obsolete and they are replaced by new ones. Furthermore, the accelerating pace of technology development results in an accelerating pace of computer replacement. Old computers become waste and they need to be taken care of. This is in itself a big challenge causing significant environmental and human health concerns. However, the way this is handled causes more concern. Often computer waste is sent to developing countries which lack regulation, experience, resources, or the political will to take care of computer waste in a professional way. All this creates a really nasty situation for the environment and the people who handle this waste.

There is no generally accepted truth about issues of ICT, environment and sustainability. In general terms most of us do agree on what should be done to sustain our environment or our way of life. But when we move closer to concrete projects like road construction, location of production plants and the like, conflicting opinions or dilemmas take over. Often most of the arguments are based on very good sustainability grounds although they are not compatible with each other. Eventually we will stand in front of the same problem as the one in ICT, i.e., to find a solution that works with the concrete project at hand and which may differ to the solution belonging to 
another project. All of this points to the significance of the method or of the process involved in finding answers and solutions.

\section{The power of philosophy}

The distinction between content and process is important in the effort to define ethical or moral decision making. In common sense, ethics and morals are dependent on the concrete decision or the action itself. Understanding a decision or an action being ethical/moral or unethical/immoral is based mainly on a judgment of its normative qualities. The focus on values and their normative aspects is the basis of the common sense definition of ethics.

Despite its dominance, this way of thinking causes some difficulties. We may note that bad or good things follow not only from the decisions of people but also from natural phenomena. Usually sunny weather is considered a good thing, while rainy weather is not. Of course this is not perceived as something related to morality. But why not? What is the difference between humans and nature acting in certain ways? The answer is obvious: Option, choice. Although common sense does realize that, people's attachment to the normative aspects is so strong that it is not possible for them to accept that ethics is an issue of choice and option. If there is no choice, or ability of making a choice, then there is no issue of ethics.

Now if ethics is connected to choice then the interesting aspect is how the choice is made, or not made; whether it is made in a bad or in a good way. The focus here is on how, not on what; on the process not on the content or the answer. Indeed, regarding the effort to make the right decision, philosophy and psychology point to the significance of focusing on the process of ethical decision making rather on the normative content of the decision.

Starting from one of the most important contributions, the Socratic dialog, we see that aporia is the goal rather than the achievement of a solution to the problem investigated. Reaching a state of no knowledge, that is, throwing aside false ideas, opens up for the right solution. The issue here for the philosopher is not to provide a ready answer but to help the other person in the dialog to think in the right way. It is about a skill [6]. Ability to think in the right way is not easy and apparently has been supposed to be the privilege of the few able ones [7-9]. For that, certain skills are necessary, such as Aristoteles's phrónesis [2]. When humans are free from false illusions and have the necessary skills they can use the right method to think in order to be able to find the right solution to their moral problems [1]. This is the autonomous way of thinking according to Kant [3].

This philosophical position has been applied in psychological research on ethical decision making. Focusing on the process of ethical decision making psychological research has shown that people use different ways to handle moral problems. According to Piaget [5] and Kohlberg [4], when people are confronted with moral problems they think in a way which can be described as a position on the heteronomyautonomy dimension. ICT systems have many advantages that can be used to stimu- 
late autonomous thinking during a process of ethical decision making, for example in designing systems adapted to important values.

\section{References}

1. Arendt, H.: Responsibility and judgement. Shocken, New York (2003).

2. Aristoteles.: Nicomachean ethics. Papyros, Athens (1975).

3. Kant, I.: Grundläggning av sedernas metafysik, trans. Daidalos, Stockholm (2006).

4. Kohlberg, L.: The Just Community: Approach to moral education in theory and practice. In: Berkowitz, M., Oser, F. (eds.) Moral education: Theory and application, pp. 27-87. Lawrence Erlbaum Associates, Hillsdale, NJ (1985).

5. Piaget, J.: The moral judgment of the child, trans. Routledge and Kegan Paul, London (1932).

6. Platon.: Protagoras. I. Zacharopoulos, Athens (1981a).

7. Platon.: Theaitetos. I. Zacharopoulos, Athens (1981b).

8. Platon.: Apologia. Sokratoys. Kaktos, Athens (1982).

9. Platon.: Politeia. Kaktos, Athens (1992).

10. Tavani, H.T.: Philosophical theories of privacy: Implications for an adequate online privacy policy. Metaphilosophy, 38: 1-22(2007). 